\title{
Seroprevalence of cytomegalovirus among pregnant women attending Murtala Mohammed Specialist Hospital Kano, Nigeria
}

\author{
Hamid K.M., ${ }^{1 . *}$ Onoja A.B., ${ }^{2}$ Tofa U.A. ${ }^{3}$ and Garba K.N. ${ }^{4}$
}

\author{
1.School of Medical Laboratory Science, Usmanu Danfodiyo University Sokoto, \\ Nigeria \\ 2.Department of Virology, College of Medicine, University of Ibadan, Nigeria \\ 3.Microbiology Department, Aminu Kano Teaching Hospital Kano, Nigeria \\ 4.World Health Organization Polio Reference Laboratory, Ibadan, Nigeria
}

\begin{abstract}
Background: Primary Cytomegalovirus (CMV) infection during pregnancy is a frequent and serious threat to the fetus. As there is no vaccine alternative measures are needed to prevent congenital CMV infection.

Objective: This study determined CMV Immunoglobulin $\mathrm{G}(\mathrm{IgG})$ antibody among pregnant women in order to ascertain the immune status of mothers to guide policy makers.

Methods: A semi-structured questionnaire was initially administered to obtain information on demographic details, stage of pregnancy and risk factors. Blood was collected by venipuncture from 180 women attending the antenatal clinic in Murtala Mohammed Specialist Hospital Kano, Kano State, Nigeria. Sera samples were screened using CMV IgG ELISA kit (Dialab, Austria).

Results: Out of 180 pregnant women, $164(91.1 \%)$ were seropositive. Based on stages of pregnancy 6/6(100\%), 52/60(86.7\%) and 106/114(93.0\%) were seropositive among women in the first, second and third trimesters respectively.

Conclusion: Seroprevalence of pregnant women to CMV Ig G is high, hence the need for CMV - IgM screening to know the extent of active infection. There is also need for public enlightenment on the methods of transmission, effective prevention and control strategies.
\end{abstract}

Keywords: CMV; pregnant women; immunoglobulin G; seropositivity; Nigeria

African Health Sciences 2014;14(1): 125-130 http://dx.doi.org/10.4314/ahs.v14i1.19

\section{Introduction}

Human Cytomegalovirus (CMV) is a ubiquitous virus which is contracted either vertically and/or horizontally. Also, it can be transmitted through primary infection; re-infection or reactivation. ${ }^{1}$ The virus sometimes causes minimal disability, allowing infected individuals to remain active in order to afford maximum opportunity of encountering susceptible contacts. It is excreted from multiple sites as such varying degrees of intimacy can lead to transmission. ${ }^{2}$ The virus is incriminated as an opportunistic infection in many parts of the world. ${ }^{1}$ Acute CMV disease occur in a small proportion of infected individuals, and is restricted to settings where ability to mount cellular immune response is compromised, such as transplacental transmission during pregnancy leading to fetal damage and reactivation or primary infection of immunocompromised individuals. Transmission infected bodily secretions; thus hygiene and virus shedding patterns remain important determinants of in the

\section{Corresponding author: \\ Onoja A.B. \\ Department of Virology, \\ College of Medicine, \\ University of Ibadan, Nigeria}

African Health Sciences Vol 14 No.3 March 2014 general population depends on direct contact with the transmission. ${ }^{1} \mathrm{CMV}$ infection during pregnancy is a major cause of congenital infection worldwide ${ }^{3}$ with an incidence of $0.2-2.2 \%$ of live births. ${ }^{4} \mathrm{Up}$ to $15 \%$ of such children have neurologic damage ${ }^{5,6}$ which includes impaired development, mental retardation, and neurosensory hearing deficit. ${ }^{7}$ Fetal or neonatal death occurs in about $10 \%$ of fetuses or newborns following intrauterine CMV infection. ${ }^{7}$ About $80 \%$ of adults in the world have antibody against CMV. ${ }^{8}$ Few pregnant women are routinely screened for CMV infections during pregnancy. ${ }^{7}$ Routine serological screening of pregnant women in Europe has helped their understanding of CMV infections among pregnant women. High level screening in Belgium has yielded data on maternal-fetal transmission rates at gestation. ${ }^{9}$ The Italians used national serologic screening to develop and evaluate methods to diagnose maternal and fetal CMV infections including the CMV IgG avidity assay, and to test CMV immunoglobulin interventions. ${ }^{10,11}$ The French used serologic screening to evaluate the role of maternal education on CMV and the role of hygienic intervention to prevent maternal acquisition during pregnancy. ${ }^{12}$ Nigeria is grappling with inadequate funding in the health sector, and managing conditions such as congenital CMV disease is an issue, hence the need to investigate the IgG level with a view 
to guiding policy makers and educating pregnant mothers on ways of preventing infection to reduce birth of otherwise helpless children.

\section{Material and methods}

\section{Study area / population}

Samples were collected from a cross-section of pregnant women attending the antenatal clinic of Murtala Mohammed Specialist Hospital (MMSH) Kano, Kano State, Nigeria. Sample size was calculated using formula $\mathrm{n}=\mathrm{N} / 1+\mathrm{N}(\mathrm{d})^{2}$ to get 361pregnant women, where $\mathrm{N}=$ population size, $\mathrm{d}=$ level of precision. ${ }^{13}$ One hundred and eighty-one pregnant women were randomly selected from an average of 3700 pregnant women attending the antenatal clinic. Ethical approval was obtained from the MMSH Management Board and informed consent was sought and obtained before collection of the blood samples.

\section{Sample collection and processing}

About $5 \mathrm{ml}$ of venous blood was collected from each patient using a 23gauge needle and syringe. The blood was transferred into a test tube and labeled properly with patient's identification number. The blood sample was centrifuged at $3,000 \mathrm{~g}$ for $5 \mathrm{mins}$. The serum was obtained using Pasteur pipette and transferred into clean cryovials and stored at $-20^{\circ} \mathrm{C}$, until representative samples were obtained.

\section{ELIS A procedure}

Qualitative determination of CMV IgG antibodies was carried out using Enzyme Linked Immunosorbent Assay (ELISA) technique using CMV IgG kit (Dialab ${ }^{\circledR}$, Austria). Samples, reagents and calibrators were brought to room temperature before the test. Microwell plate was labeled for sample, control and blank ap- propriately. Samples were diluted 1:100 with the sample diluents. Afterwards $100 \mu$ l of each sample, positive and negative controls were dispensed into wells, leaving a well empty (blank). The plate was covered with adhesive foil (VWR ${ }^{\circledR}$, USA) and incubated at $37^{\circ} \mathrm{C}$ for 60 minutes using an incubator (NAPCO, Thermo electron corporation). The adhesive foil was gently detached and plate washed seven times with $300 \mu$ l diluted wash buffer (Biotek ${ }^{\circledR}$ plate washer). $100 \mu$ l of enzyme conjugate was then introduced into all wells, covered again and incubated at $37^{\circ} \mathrm{C}$ for another 60 minutes. It was washed again seven times with $300 \mu$ l diluted wash buffer. Then $100 \mu \mathrm{l}$ of the substrate was dispensed into all the wells including the blank. The plate was covered with a new adhesive and this time incubated at room temperature for $20 \mathrm{~min}$, protected from light after which $100 \mu \mathrm{l}$ of stop solution was finally introduced in all the wells. The absorbance of each sample, control and blank were read using SoftMax Pro 5.4 software with Molecular devices ${ }^{\circledR}$ plate reader at a wavelength of $450 \mathrm{~nm}$. The cutoff of IgG was set at 0.5 World Health Organization (WHO) IU $/ \mathrm{m}$. Samples with a concentration $\geq 0.5$ WHO IU $/ \mathrm{mL}$ were considered positive for CMV IgG, while samples with a concentration below the cut off were considered as negative results.

\section{Statistical analysis}

Statistical analysis of results was done using the statistical package for social science (SPSS 16.0, IBM, USA). Pearson chi square test was used for the assessment and the differences were considered to be statistically significant at $P<0.05$.

\section{Results}

Of the 180 pregnant women screened, 164 (91.1\%) had CMV IgG antibodies while 16 (8.9\%) had none as shown in Table 1.

\section{Table 1. Distribution of CMV IgG antibody in pregnant women by age group}

\begin{tabular}{lccl}
\hline Age group & No. of women & Seropositive $(\%)$ & Seronegative (\%) \\
\hline $17-20$ & 42 & $40(95.2)$ & $2(4.7)$ \\
$21-24$ & 24 & $18(75.0)$ & $6(25.0)$ \\
$25-28$ & 52 & $48(92.3)$ & $4(7.7)$ \\
$29-32$ & 38 & $38(100)$ & $0(0.0)$ \\
$33-36$ & 24 & $20(83.3)$ & $4(16.7)$ \\
Total & 180 & $164(91.1)$ & $16(8.9)$ \\
\hline
\end{tabular}


There was no significant difference between the CMV IgG level within the age groups ( $\mathrm{P}>0.05)$. Based on occupational status, the unemployed 120 had higher IgG level compared to the self employed 38 and civil servants 6 in Table 2.

Table 2. Distribution of CMV IgG antibody by occupation and stage of pregnancy

\begin{tabular}{lll}
\hline Variable & No. of women & Seropositive $(\%)$ \\
\hline Occupation & & $6(100)$ \\
Civil Servant & 6 & $38(95.0)$ \\
Self employed & 40 & $120(89.5)$ \\
Unemployed & 134 & \\
Stage of pregnancy & 6 & $6(100)$ \\
$\begin{array}{l}\text { 1st trimester } \\
\text { 2nd trimester }\end{array}$ & 40 & $52(86.7)$ \\
3rd trimester & 114 & $106(93.0)$ \\
\hline
\end{tabular}

Based on stage of pregnancy, Table 2 also shows 6 women in the first trimester have $\mathrm{IgG}$ antibodies, in the second trimester 52 had antibodies
CMV IgG antibody in the third trimester was highest $106(93.0 \%)$ while $8(7.0 \%)$ were seronegative. Table 3 shows that out of the 168 women not transfused, 154 $(91.7 \%)$ had antibodies.

Table 3. Distribution of CMV IgG antibody according to blood transfusion status and parity

\begin{tabular}{llll}
\hline & & No. of women & Seropositive $(\%)$ \\
\hline \multirow{3}{*}{ Blood transfusion } & Not transfused & 168 & \\
& Transfused & 12 & $154(91.7)$ \\
Previous pregnancy & $1-2$ & 50 & $10(83.3)$ \\
& $3-4$ & 44 & 44 \\
& $\geq 5$ & 86 & 80 \\
& & \\
\hline
\end{tabular}

There was a significant difference between CMV IgG level among women who were not transfused and those who were $(p<0.05)$. Out of the12 women transfused, $10(83.3 \%)$ had antibodies.
Based on parity (table 3) women with 1, 2, $\geq 5$ numbers of pregnancies had higher number of people with $\operatorname{IgG}$ antibodies. Of the 44 women with 3 - 4 pregnancies 40 (24.4\%) had IgG antibody. 


\section{Discussion}

The gold standard for detecting maternal seroconversion with regards to antibodies against CMV is serological diagnosis. The IgG assay is nearly 100\% sensitive and specific, readily available, and automated for high volume capacities. ${ }^{14,15}$ The high anti-CMV antibody of $91.1 \%$ observed among pregnant women in $\mathrm{MMSH}$ Kano is due primary infection and/or secondary infection with intermittent excretion of virus as a result of reactivation of an endogenous virus or exposure to new virus strain from exogenous sources. This is similar to a study among 5,959 pregnant women in Izmir Turkey ${ }^{16}$ in which $98.3 \% \operatorname{IgG}$ seropositivity was observed; 179 pregnant women in Lagos southwest Nigeria where pregnant women had 97.2\% anti-CMV IgG antibodies. ${ }^{17}$ This is higher than the range of $60-70 \%$ in urban U.S. cities ${ }^{18}$ but comparable to women of childbearing age in Singapore, Thailand ${ }^{9}$ and in Iran. ${ }^{19}$ Our findings in table 2 show that unemployed people had the highest CMV IgG seroprevalence of $89.5 \%$. It was reported as early as 1973 that CMV antibodies was more prevalent in developing countries especially in areas of lower socioeconomic conditions in comparison to developed countries. $^{20}$

High seropositivity in $2^{\text {nd }}$ and $3^{\text {rd }}$ trimesters (Table 3 ) is in line with a report that recurrent infection occurs most frequently in the last two trimesters where marked transient depression of CMV- specific cellular immunity can be demonstrated. ${ }^{21}$ Although $83.3 \%$ seropositive pregnant women with history of blood transfusion were identified in this study, high seropositivity has been extensively reported in transfusion-associated CMV. ${ }^{22,23}$ Similarly, 96\% anti-CMV IgG and 19.5\% anti-CMV IgM seroprevalence was reported amongst apparently healthy blood donors in Lagos, Nigeria. This is quite significant because one out of every four units of blood donated is acutely infected by CMV. ${ }^{24}$ This study observed high seroprevalence with increased parity (Table 5). This finding is contrary to a study among pregnant women in London which reported high $(88.2 \%)$ seroprevalence in first pregnancies among women. ${ }^{25}$ The high seroprevalence we observed could be due to reactivation or re-infection with different strains of CMV. Most Nigerian women have more than one child and love to be around children from other families even when they are pregnant, some shedding the virus, which underscores the problem of silent viral infection during pregnancy. Currently, the American College of Obstetricians and Gynecologists (ACOG) recommends that all women be educated about the ways that CMV infection may be acquired in pregnancy. ${ }^{26}$ They recommend careful handling of potentially infected articles, such as diapers, and thorough hand washing when around young children or immunocompromised individuals. This is especially true for women who work in daycare settings and for those who are pregnant. ${ }^{27-33}$

\section{Limitations of this study}

The sample size was halved because of financial constraints. The authors preferred to detect anti-CMV IgG avidity to investigate recent acute infection and identify pregnant women at increased risk of having infected fetuses but could not due to financial constraints as well.

\section{Conclusion}

A significant proportion of pregnant women in parts of Kano metropolis are exposed to CMV infection. We recommend that health policies should include routine CMV-IgM screening or detection of anti-CMV Ig G avidity for pregnant women, compulsory CMV antibody screening of blood to be transfused to premature infants, pregnant women and immunocompromised individuals.

\section{Conflict of Interest}

The authors declare that there is no competing interest.

\section{References}

1. Mocarski ES, Shenk T. and Pass RF. Cytomegalovirus. In: Fields virology 5th Ed. Lippincot Williams and Wilkins Eds Knipe D.M, Howley P.M. 2007. p2702

2. Giffiths P.D. Cytomegalovirus. In: Principles and Practice of clinical virology 6th Ed, Eds A.J. Zukerman, J.E. Banatvala, Schoub B.D., Griffiths P.D. and Mortimer P. John Wiley \& Sons Ltd 2009. p166

3. Rubin R.H. Cytomegalovirus Infections: Epidemiology, Diagnosis and Treatment Strategies. Rev. Infect. Dis 1990;12:711-719

4. Stagno S. Cytomegalovirus. In: JS, Remington and JO Klein Eds. Infectious disease of the fetus and newborn infant 3rd ed Philadelphia, PA: WB Saunders, Co. 1990 pp $242-281$.

5. Fowler KB, Stagno $S$ and Pass RF. Maternal age and congenital cytomegalovirus infection screening of two diverse newborn populations $1980-1990$. J infect Dis 1993;168:552- 6. doi: 10.1093/jinfdis/168.3.552

6. Fagbami A.H. Medical Virology: Lecture supplements. Nihinco Prints Mokola, Ibadan 2008. p139-42 
7. Adler S.P. Screening for Cytomegalovirus during Pregnancy. Infectious Diseases in Obstetrics and Gynecology 2011;9 doi:10.1155/2011/942937

8. Gladwin, M., Trattler, B. 2002. Retroviridae, HIV and AIDs. In: Clinical Microbiology Made ridiculously simple 3rd edition Medmaster, Inc. U.S.A. 2002. p195

9. Bodéus M., Kabamba-Mukadi B., Zech F., Hubinont C., Bernard P. and Goubau P. Human cytomegalovirus in utero transmission: follow-up of 524 maternal seroconversions. Journal of Clinical Virology 2010;2:201-2. 10. Lazzarotto T., Spezzacatena P., Varani S., Gabrielli L, Pradelli P, Guerra B, et al., Anticytomegalovirus (Anti-CMV) immunoglobulin $\mathrm{G}$ avidity in identification of pregnant women at risk of transmitting congenital CMV infection. Clinical and Diagnostic Laboratory Immunology. 1999;1:127-129.

11. Nigro G., Adler S.P., Torre R. La, and Best A.M. Passive immunization during pregnancy for congenital cytomegalovirus infection. The New England Journal of Medicine. 2005;13:1350-62. doi: 10.1056/NEJMc052894.

12. Vauloup-Fellous C., Picone O., Cordier A.G., Parent-du-Chatelet I., Senat M.V., Frydman R., et al. Does hygiene counseling have an impact on the rate of CMV primary infection during pregnancy? Results of a 3-year prospective study in a French hospital. Journal of Clinical Virology. 2009;4:49-53. doi: 10.1016/j. jcv.2009.09.003.

13. Yamane T. Statistics: An introductory analysis 2nd Ed. New York: Harper and Row 1967; p886-7

14. Lagrou K, Bodeus M, Van Ranst M, Goubau P. Evaluation of the new architectcytomegalovirus immunoglobulin M (IgM), IgG, and IgG avidity assays. J of Clin.Microbiology. 2009;47:1695-9. doi: 10.1128/ JCM.02172-08

15. Carlier P, Harika N, Bailly R. and Vranken G. Laboratory evaluation of the new accesscytomegalovirus immunoglobulin $\mathrm{IgM}$ and $\mathrm{IgG}$ assays. Journal of ClinicalVirology.2010;49:192-7. doi:10.1016/j. jcv.2010.07.024

16. Uysal A, Taner CE, Cüce M, Atalay S, Göl B, Köse S, Uysal F.Cytomegalovirus and rubella seroprevalence in pregnant women in Izmir/Turkey: follow-up and results of pregnancy outcome. Arch Gynecol Obstet. 2012;286(3):605-8. doi: 10.1007/s00404-012-2353-z.

17. Akinbami AA, Rabiu KA, Adewumi AA, Wright $\mathrm{KO}$, Dosunmu AO, Adeyemo TA, et al.Seroprevalence of CMV-IgG antibodies amongst normal pregnant women in Nigeria. IntJ Womens Health 2011;3:423-8. doi: 10.2147/IJWH.S24850

18. Zhang LJ, Hanpf P, Rutherford C, Churchill WH, Crumpacker CS. Detection of human cytomegalovirus DNA, RNA, and antibody in normal donor blood J. Infect Dis 1995;171:1279-1289.

19. Arabpour M, Kariyanee K, Jankhah A, and Yaghobi R. Human cytomegalovirus in women of child bearing age throughout Fars province-Iran: A population based cohort study. Malaysian Journal of Microbiology 2007;3:23-8.

20. Krech Y. Complement fixing antibodies against CMV in different parts of the world. Bull World Health Organization. 1973;49:103-6.

21. Gehrz RC, Christainson WR, Linner KM, Conroy MM, McCue SA, and Balfour HH. Cytomegalovirus specific humoral and cellular immune response in human pregnancy, J. infect Dis 1981;143:391- 5

22. Bayer WL and Tegtemeier GE. The blood donor and magnitude of CMV carrier status and the prevalence of CMV antibody. Yale J Biol Med. 1976; 49:512. 23. Gaytant MA, Steegers EAP, Semmekrot BA, Merkus MW, Galama MD. Congenital cytomegalovirus infection: review of the epidemiology and outcome. Obstet Gynecol Surv. 2002;57:245-56.

24. Akinbami AA, Akanmu AS, Adeyemo TA, and Dosunmu AO. Seroprevalence of CMVantibodies among HIV patients and blood donors at Lagos State University Teaching Hospital. S Afr Med J. 2009;99:528-30.

25. Tookey PA, Ades AE, Peckham CS. Cytomegalovirus prevalence in pregnant women:the influence of parity. Arch Dis Child.1992;67:779-83

26. American College of Obstetricians and Gynecologists (ACOG), authors Perinatal Viral and Parasitic Infections. Washington, DC, 2000. Practice Bulletin No. 20.

27. Adler S.P. Cytomegalovirus and child day care: evidence for an increased infection rate among daycare workers. The New England Journal of Medicine 1989;19:1290-6.

28. Ballow M. Mechanisms of action of intravenous immune serum globulin therapy.Pediatric Infectious Disease Journal. 1994:9:806-11.

29. Clark AL and Gall SA. Clinical uses of intravenous immunoglobulin in pregnancy.American Journal of Obstetrics and Gynecology 1997;1:241-53.

30. Keller M.A. and Stiehm E.R. Passive immunity in prevention and treatment of infectiousdiseases. Clinical Microbiology Reviews 2000;4:602-14

31. Porath A, McNutt R.A, Smiley L.M and Weigle K.A. Effectiveness and cost benefit of a proposed live cy- 
tomegalovirus vaccine in the prevention of congenital disease," Reviews of Infectious Diseases. 1990;1:3140.doi: $10.1093 /$ clinids/12.1.31

32. Goodnight W., Soper D. and Simpson K. Cost-effectiveness of antenatal maternal CMV serologic screening for reduction of congenital CMV sequelae. In: Proceedings of the 34th Annual Meeting of the Infectious
Disease Society for Obstetrics and Gynecology, 2007.

33. Cahill A.G., Odibo A.O., Stamilio D.M. and Macones G.A. Screening and treating for primary cytomegalovirus infection in pregnancy: where do we stand? A decision analytic and economic analysis. American Journal of Obstetrics and Gynecology. 2009;5:4661-7 